\title{
Identification and Characterization of a New Gene Physically Linked to the ATM Gene
}

\author{
Takashi Imai, ${ }^{1,3}$ Masatake Yamauchi, ${ }^{1}$ Naohiko Seki, ${ }^{2}$ \\ Takehiko Sugawara, ${ }^{1}$ Toshiyuki Saito, ${ }^{1}$ Yoichi Matsuda, ${ }^{1}$, Hiroko Ito, ${ }^{1}$ \\ Takahiro Nagase, ${ }^{2}$ Nobuo Nomura, ${ }^{2}$ and Tada-aki Hori ${ }^{1}$
}

\author{
${ }^{1}$ Genome Research Group, National Institute of Radiological Sciences, Inage-ku, Chiba 263, Japan; \\ ${ }^{2}$ Laboratory of Gene Structure I, Kazusa DNA Research Institute, Kisarazu, Chiba 292, Japan
}

\begin{abstract}
Ataxia telangiectasia (AT) is an autosomal recessive disease of unknown etiology associated with cerebellar ataxia, oculocutaneous telangiectasia, immunodeficiency, and hypersensitivity to ionizing radiation. Although AT has been divided into four complementation groups by its radioresistant-DNA synthesis phenotype, the ATM gene has been isolated as the candidate gene responsible for all AT groups. We identified a new gene, designated NPAT, from the major AT locus on human chromosome llq22-q23. The gene encoded a 1421-amino-acid protein containing nuclear localization signals and phosphorylation target sites by cyclin-dependent protein kinases associated with E2F. The messenger RNA of NPAT was detected in all human tissues examined, and its genomic sequence was strongly conserved through eukaryotes, suggesting that the NPAT gene may be essential for cell maintenance and may be a member of the housekeeping genes. Analysis of the genomic region of NPAT surprisingly revealed that the gene existed only $0.5 \mathrm{~kb}$ apart from the $5^{\prime}$ end of the ATM transcript with opposite transcriptional direction. It may be possible to propose the idea that the promoter region could be shared by both housekeeping genes and that each gene could influence the expression of the other.
\end{abstract}

Ataxia telangiectasia (AT) is an autosomal recessive gene disorder defined by a wide spectrum of defects involving a severe neurological disorder attributable to progressive degeneration of the cerebellum, particularly the Purkinje cells, dilation of blood vessels in the eyes, ears, and face, immunological defects such as atrophy of the thymus and diminished $\mathrm{T}$ cell response, a greatly elevated incidence of tumors, especially of leukemia and lymphomas, and premature aging (for review, see Harnden 1994; Shiloh 1995). In addition, AT heterozygotes, estimated in $\sim 1 \%$ of the population, have a fivefold increased risk of neoplasia, particularly breast carcinoma in women (Swift et al. 1991), although the disease is known to have an autosomal recessive inheritance.

At the cellular level, AT cells exhibit an unusual response to DNA synthesis after ionizing radiation exposure (i.e., radioresistant DNA synthesis) (Houldsworth and Lavin 1980; Painter and Young 1980). There were defects in the

${ }^{3}$ Corresponding author.

E-MAIL imait@nirs.go.jp; FAX + 81-43-251-9818. checkpoint function at all phases of the cell cycle shortly after irradiation, allowing the cells to continue cycling despite extensive DNA damage (for review, see Hartwell and Kastan 1994; Thacker 1994). AT cells also show a delayed induction of proteins associated with cell-cycle arrest, p53, or DNA replication and repair, replication protein A (Kastan et al. 1992; Khanna and Lavin 1993; Liu and Weaver 1993; Lu and Lane 1993; for review, see Thacker 1994). These data indicate that the wild type of the AT gene products may act in an early step in a specific DNA damage-signaling pathway (Liu and Weaver 1993; Thacker 1994).

The property of radioresistant DNA synthesis was used to perform genetic complementation tests, suggesting that the AT could be divided into four complementation groups, AT-A, AT-C, AT-D, and AT-E (Jaspers et al. 1988). Genetic linkage analyses, however, showed that the genes responsible for at least groups A, C, and E were mapped to the same region on chromosome 11q22-q23 (Gatti et al. 1988; Ziv et al. 1991; McConvill et al. 1993). Although genetic linkage evidence did not support the hypothesis of genetic heterogeneity, the possibility of a cluster of genes at the 11q22-q23 locus could not be ruled 
out (McConvill et al. 1994). The gene responsible for complementation of the D group (ATDC) was also mapped to chromosome 11q22-q23; however, the detailed location of the gene was outside of the major AT region for the other three AT groups (Kapp et al. 1992; Leonhardt et al. 1994). The candidate gene responsible for ATDC was cloned and analyzed but no mutation, so far, has been reported in this gene in ATD patients (Leonhardt et al. 1994). Linkage analysis by Sobel et al. (1992) suggested genetic heterogeneity with possible gene loci in the STMY-D11S132 interval for groups $A$ and $C$ and in the more distal D11S147-D11S133 interval for group D. In addition, Sanal et al. (1992) concluded that at least two distinct loci, $A$ and $D$, existed with perhaps a third locus very near the AT-A gene.

Recent haplotype analysis by the international consortium has indicated that the major AT locus, AT-A/AT-C, is localized to an $~ 850-\mathrm{kb}$ interval flanked by D11S1818 and D11S1819 (Gatti et al. 1994). More recently, the gene responsible for AT, ATM, has been identified by positional cloning on the major AT locus (Savitsky et al. 1995a,b). The ATM was found to be mutated in AT patients from all complementation groups, indicating that it is probably the sole gene responsible for this disorder (Savitsky et al. 1995a). The predicted protein of 3056 amino acids revealed significant sequence similarities to the proteins containing phosphatidylinositol-3 kinases (PI-3 kinases), such as the Saccharomyces genes TOR1 (Cafferkey et al. 1993) and TOR2 (Kunz et al. 1993), the Schizosaccharomyces pombe rad3 gene (Savitsky et al. 1995b), Saccharomyces ESR1/MEC1 (Hari et al. 1995; Paulovich and Hartwell 1995), DNA-dependent protein kinase (Hartley et al. 1995), and Saccharomyces TEL1 (Greenwell et al. 1995; Morrow et al. 1995). It is very interesting that these candidates of the ATM family are shown to be involved in mitogenic signal transduction, meiotic recombination, and cell-cycle control.

No experimental data, however, have been reported regarding whether the ATM gene can compensate the cellular defects in two AT phenotypic hallmarks, radiosensitivity and radioresistant-DNA synthesis. It also remains to be determined whether the ATM product has PI-3 kinase or DNA-dependent protein kinase activity or whether it can bind DNA.

Our attempt was to screen more genes transcribed from the major AT region in a yeast artificial chromosome (YAC) contig (Imai et al. 1995) to examine their possible functions related to some complicated phenotypes of AT. Here we describe a new housekeeping gene that lies only 0.5 $\mathrm{kb}$ apart from the $5^{\prime}$ end of the ATM transcribed region with the opposite transcriptional direction.

\section{RESULTS}

\section{Isolation of cDNA Clones}

The major AT region on chromosome 11 lies between D11S1818 and D11S1819 and is estimated to encompass $850 \mathrm{~kb}$ (Gatti et al. 1994). From a YAC contig, which covered $2 \mathrm{Mb}$ of DNA at the boundary between the Giemsa-positive band $11 \mathrm{q} 22.3$ and the Giemsa-negative band 11q23.1 and included the entire region of the major AT locus (Imai et al. 1995), three YAC clones were chosen and subjected to the island rescue PCR (IRP) (Valdes et al. 1994) for searching the transcribed sequences. Amplified DNA fragments by IRP extending from BssHII or SacII sites to the nearest $A l u$ repeat in the YAC clones were used to screen a human testis cDNA library. Three cDNA clones were isolated from the library consisting of $6 \times 10^{5}$ clones and these, designated as T4-41, T4-51, and T4-92, were confirmed to be derived from at least one of the YACs by Southern blot analysis of the restriction enzyme-digested fragments of the YACs. Nucleotide sequence analysis of these clones revealed that no identical nucleotide sequence, except some expressed sequence tagged sites (ESTs), could be identified in any public data bases. Because the Southern hybridization analysis also indicated that the T4-41 clone is located at the center of the major AT locus, we focused on T4-41 for further characterization.

Northern blot analysis using poly $(\mathrm{A})^{+}$RNA from various human tissues with the T4-41 clone as the probe showed two hybridizing signals of 6.2 and $5.4 \mathrm{~kb}$. These bands were detected in all of the tissues examined, indicating that the gene was widely expressed but both the expression levels and the quantitative ratio of the two RNA species were slightly different in each tissue (Fig. 1). An evolutionary conservation test of the T4-41 sequence using genomic DNA from various vertebrates and budding yeast revealed that the gene was strongly conserved through mammals (Fig. 2). Relatively weak but positive signals were detected in chicken and yeast DNAs, showing that the gene was conserved through eukaryotes. These results imply that the T4-41 gene may be a member of the housekeeping genes. 


\section{NEW GENE IN AT LOCUS}

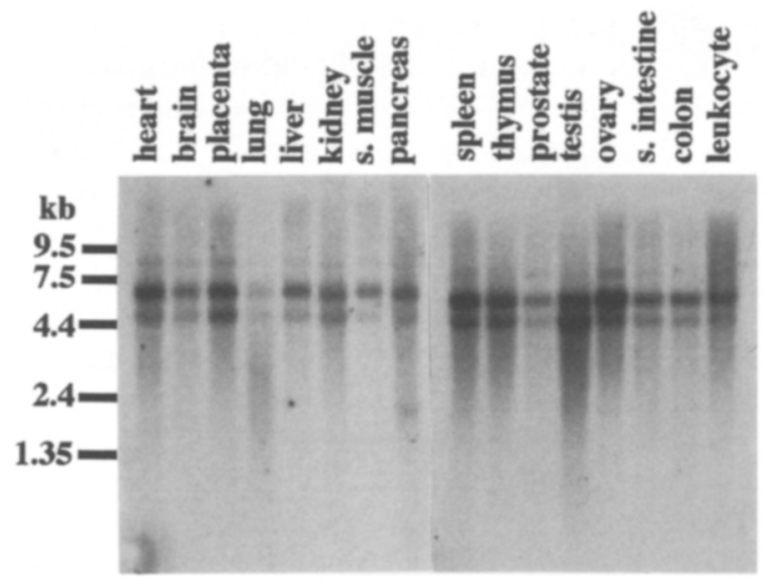

Figure 1 Expression analysis of T4-41 gene. Insert DNA was excised from the T4-41 cDNA clone and labeled with [ $\left.{ }^{32} \mathrm{P}\right] \mathrm{dCTP}$ by the random priming method (Feinberg and Vogelstein 1984). The blots (MTN I and MTN II) containing $\sim 2 \mu \mathrm{g}$ of poly(A) RNA per lane from 16 different human tissues were obtained from Clontech Laboratories (Palo Alto, CA).

Because the insert of the T4-41 cDNA clone did not extend to the length of the poly $(\mathrm{A})^{+}$RNA detected by the Northern blot hybridization, other cDNA libraries from human testis and placenta were further screened using various restriction fragments excised from the insert DNA of T4-41, and four clones positive for hybridization were recovered (Fig. 3). Nucleotide sequence analysis of all isolated clones permitted the construction of a 5900-base continuous sequence excluding a poly(A) tail.

The composite sequence of B-39, T4-41, T481, and T4-82, designated NPAT (nuclear protein mapped to the AT locus; discussed below), was obtained from both the message and complementary strands. There was complete agreement in the nucleotide sequences obtained from the overlapping areas. The NPAT cDNA contained 66 nucleotides in the 5'-noncoding region, 4281 nucleotides in the coding region, and 1553 nucleotides in the 3 '-untranslated region preceding the poly(A) tail [DDBJ (DNA Data Base of Japan)/EMBL/GenBank accession no. D83243]. There is an in-frame stop codon $43 \mathrm{bp}$ upstream of the putative start codon. The 3 '-untranslated region contains the hexanucleotide $5^{\prime}$-AATAAA$3^{\prime}$, which could function as a signal for $\operatorname{poly}(\mathrm{A})$ addition or termination of transcription (Proudfoot and Brownlee 1976) in the expected position, 23 nucleotides upstream from the poly(A) tail.

\section{Predicted Amino Acid Sequence of NPAT}

The total length of the predicted protein was 1427 amino acids with a calculated molecular mass of 154,300 (any modified residues not included) (Fig. 4). The protein was relatively serine/ threonine rich, $21.3 \%$ of the total amino acid residues of the protein, and was acidic.

To predict localization of the protein in a cell, the deduced amino acid sequence was subjected to the PSORT analysis through the network service of the Institute for Molecular and Cellular Biology, Osaka University, Osaka, Japan (Nakai and Kanehisa 1992), suggesting that the protein may be transported into the nucleus because it had sequences matching the nuclear localization signals consisting of four continuous basic amino acids in the carboxyl terminus (Fig. 4 ). No existence of a signal sequence or a leader peptide, which is thought to be necessary for protein sorting through the vesicular pathway, was proposed by this analysis. Therefore, the gene was tentatively designated NPAT.

The data base search with the whole NPAT nucleotide and deduced amino acid sequences found no significant similarity with any previous known genes but detected weak homologies with yeast cdc24 (Bender and Pringle 1992), human

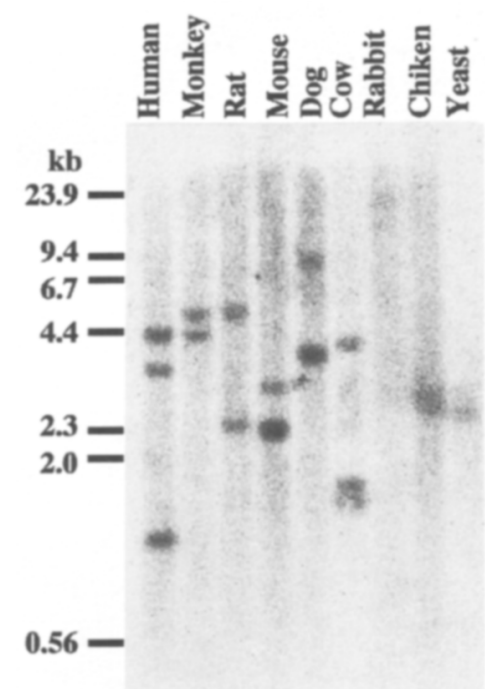

Figure 2 Cross-hybridization of T4-41 cDNA and total genomic DNA from different species. The insert fragment was isolated from the T4-41 cDNA and used for hybridization as the probe. The Southern blot containing $4 \mu \mathrm{g}$ of genomic DNA per lane from nine eukaryotic species was supplied from Clontech Laboratories. 
IMAI ET AL.

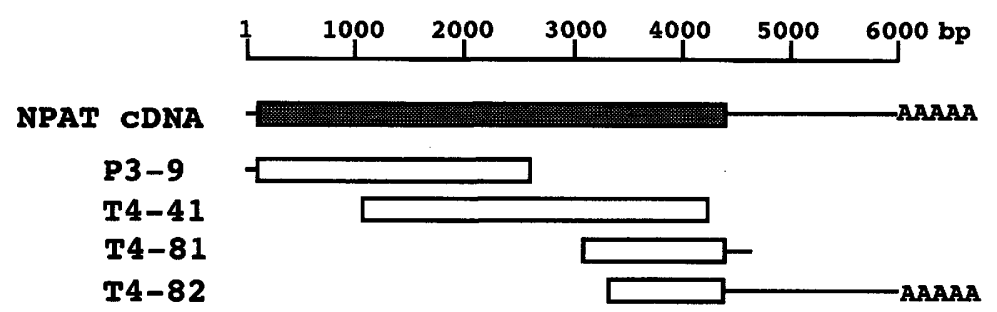

Figure 3 Schematic diagram of overlapping cDNA clones. The clones were isolated from testis (T4) and placenta (P3) CDNA libraries. The T4-81 clone contained poly $(A)$ at its $3^{\prime}$ end. There was no typical poly $(A)$ addition signal in the appropriate position of the T4-81 clone, suggesting that the CDNA clone might be synthesized by priming from the adenine-rich stretch just posterior of the $3^{\prime}$ end of the mRNA with oligo(dT) in the cDNA synthesis process. However, at present, we could not exclude that the smaller RNA molecule, $\sim 4.6 \mathrm{~kb}$, was expressed in human tissues.

protein-tyrosine phosphatase zeta precursor (Krueger and Saito 1992), and human nucleoporin NUP214 (Von Lindern et al. 1992) (33.4\% similar for NPAT $1-1281 ; 38.2 \%$ similar for NPAT $1-1471 ; 36.6 \%$ similar for NPAT $1-1471$, respectively). A detailed computer analysis of smaller fragments in the NPAT product showed similarities with a large number of known protein motifs, enabling us to identify the region with possible functional importance. Notable were five consensus sequences for phosphorylation by CDK4/E2F and CDK6/E2F complexes (Ser/Thrpro-X-Lys/Arg) (Nigg 1993a), 24 protein kinase C phosphorylation target sites (Ser/Thr-X-Lys/Arg) (Kishimoto et al. 1985; Woodgett et al. 1986), and three cAMP/cGMP-dependent protein kinase phosphorylation target sequences (Lys/Arg-Lys/ Arg-X-Ser/Thr) (Feramisco et al. 1980) (Fig. 4). The other interesting feature of NPAT was a similarity with a part of the heat shock protein Hsp90 family at 326-339 (Farrelly and Finkelstein 1984; Binart et al. 1989; Moore et al. 1989; Yamazaki et al. 1989; Meng et al. 1993). Of the 14 amino acid residues, 12 were identical or similar between human Hsp90 and NPAT. This region contained a sequence resembling the ATP/GTP-binding consensus sequence (Ala/Gly-X-X-X-X-Gly-Lys-Ser/ Thr) (Saraste et al. 1990), although the corresponding amino acid sequence in the heat shock proteins is not pointed out as the purine-binding domain (Fig. 4). Another resemblance to the ATP/ GTP-binding domain was found at 523-530 of the NPAT protein.

\section{Genomic Structure of NPAT $5^{\prime}$-Region}

To localize the NPAT gene on a fine physical map, cosmid libraries were constructed from the three YACs used for the gene identification, and the cosmid clones positive for human DNA were used for construction of contigs by screening the clone pool with the genes and the DNA markers that were mapped previously in the major AT locus and by the cosmid walking. Hybridization of the NPAT cDNA with the YAC and the cosmid contigs revealed that the gene was transcribed from telomere to centromere. Through the mapping of restriction enzyme cleavage sites on the cosmid contigs, we found that the same 2-kb EcoRI fragment of the contig was detected with both the oligonucleotide probe corresponding to the $5^{\prime}$ of NPAT cDNA and the $5^{\prime}$ restriction DNA fragment of ATM gene that is transcribed from centromere to telomere (Fig. 5) (Savitsky et al. 1995a).

Nucleotide sequence analysis of the $2-\mathrm{kb}$ EcoRI fragment (DDBJ/EMBL/GenBank accession no. D83244) showed that these two genes lay 513 bp apart in the opposite transcriptional direction. The data base search with the nucleotide sequence revealed that this region contained a 256bp sequence that was predicted previously to be one of the CpG islands isolated by the methylated DNA-binding column (Cross et al. 1994). Three degenerative TATA-like boxes were found in the upstream region at $782 \mathrm{bp}, 893 \mathrm{bp}$, and $918 \mathrm{bp}$ from the $5^{\prime}$ end of the NPAT cDNA. Also, two GC boxes (Thiesen and Bach 1990) existed at 179 and 195 bp upstream of the NPAT transcript. Several types of transcriptional regulation motifs including one heat shock responsible element (Fernandes et al. 1994) (102 bp apart from the 5' end of the gene) and two sites of the E2F-binding domain (La Thangue 1994) (69 and 113 bp upstream) could be predicted in the $5^{\prime}$ region of the NPAT gene that partly overlapped the first exon and intron of the ATM gene (Fig. 5). It is noteworthy that some of the promoter elements and regulatory sequences work in either orientation. Therefore, this NPAT upstream region may regulate transcription of both genes.

\section{DISCUSSION}

A close physical relationship between two genes, ATM and NPAT, in the major AT locus might suggest an important mechanism for the initiation and regulation of their expression, which could 


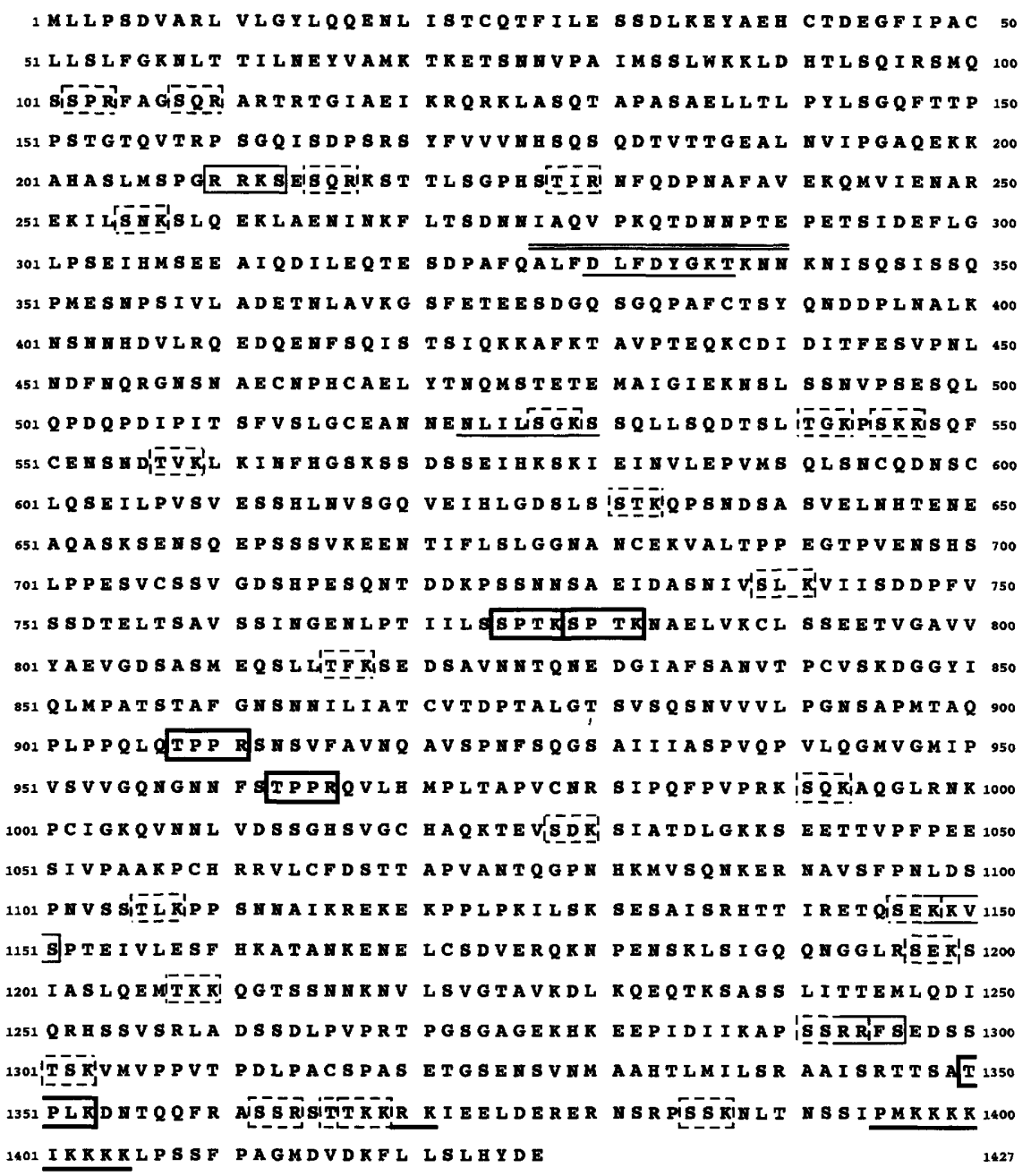

Figure 4 Amino acid sequence of the deduced translation product encoded by the NPAT gene. Putative nuclear localization signals are underlined in bold. Serine $(S)$ and threonine $(T)$ residues that are potentially phosphorylated by cdk4/E2F or cdk6/E2F complexes (bold box), CAMP-and CGMP-dependent protein kinase (plain box), and protein kinase $C$ (dashed box) are indicated. Sequences resembling the ATP/GTP-binding domain are marked by thin underlines. The upper double-lines reveals the region homologous to the hsp90 family.

affect the complex phenotypes of AT. The ATM gene has been identified as the sole gene responsible for AT because ATM was found to be mutated in AT patients from all complementation groups (Savitsky et al. 1995a). The ATM gene product has a sequence similar to the catalytic domain of PI- 3 kinase, and this similarity is shared with a group of proteins in yeast and Drosophila, all of which seem to take part in cell-cycle control in the presence of DNA damage (Savitsky et al. 1995a,b). We identified the new housekeeping gene NPAT, which lies $0.5 \mathrm{~kb}$ apart from the $5^{\prime}$ end of the ATM transcript with opposite transcriptional direction although both transcriptional startpoints have not been determined (Fig. 5). Mouse homolog of ATM and NPAT genes were also linked tightly and their localization could not be distinguished in the linkage map (Matsuda et al. 1996). The NPAT gene product probably contained nuclear localization signals at its carboxyl terminus and multiple phosphorylation target sites of cyclin-dependent kinases, which are found mainly in RB family proteins, such as pRB, p107, p130, E2F1 or p53, and SV40T (Nigg 1993b). The predicted protein of NPAT also revealed weak similarities to yeast $c d c 24$. Furthermore, the $5^{\prime}$ region of the NPAT gene contained two octanucleotides identical to the E2F-binding domain, which are identified in the genes controlling cell growth, like cmyc, N-myc, dihydrofolate reductase, DNA polymerase $\alpha$, and $c d c 2$ (Nevins 1992). These imply that the NPAT protein could be involved in cell-cycle regulation mechanisms through its phosphorylation and transportation between the nucleus and the cytoplasm.

Thus far, we have not identified any mutations of NPAT in eight Japanese AT patients in the preliminary experiments. However, it seems possible that expression of the NPAT could be affected by the ATM transcription, although the NPAT protein itself has normal function. It is also not difficult to speculate that the chromatin structure involving both genes might be maintained in a common conformation, which is thought to be related to gene activation. If the ATM gene lost its expressional control, it might cause unusual expression of the NPAT gene at a quantitative level or expression timing. It was reported that the majority of the identified 
IMAI ET AL.

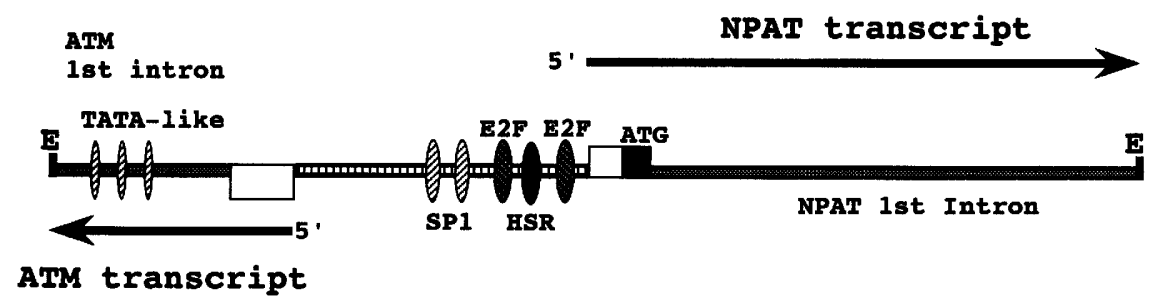

$1 \quad 0.5 \quad 1.0 \quad 1.5 \quad 2.0 \mathrm{~kb}$

Figure 5 Schematic diagram of the upstream region nestled between ATM and NPAT genes. Both genes and transcriptional directions are represented by arrows. The 5 -untranslated region in the first exon of both genes is denoted by the white boxes. The protein-coding region in the first exon of the NPAT gene is marked by a black box with ATG. The first intron of both genes is represented by shaded bars. Possible E2F-binding domains, SP1-binding sites, the heat shock responsible element, or TATA-like motifs are marked by ellipses. E reveals the EcoRI site of the genomic DNA.

mutations of ATM in the AT patients were frameshifts, which probably resulted in total loss of function of the ATM product because all of the frameshifts after truncations were reported to occur before the PI-3 kinase domain except in the case of AT103LO (Savitsky et al. 1995a). Expression of the ATM gene may respond to DNA damage after ionizing radiation. Production of the truncated molecules might not be able to shut off the predicted feedback system of ATM gene expression because the amounts of active ATM product might not be at an adequate level, keeping the promoter region of the NPAT gene also open together with that of the ATM gene. On the contrary, transcription initiation of the NPAT could decrease because the transcriptional basic factors required for the NPAT gene expression were deprived by the continuously activated, mutated ATM gene.

The ideas that the expression of both genes could influence each other and that this resulted in the complex phenotype of AT might be supported by the genetic and the clinical heterogeneity of AT (Bundey 1994). It is pointed out that although AT is almost always inherited as an autosomal recessive, there are some unusual features, such as an unexpectedly low parental consanguinity rate, an incidence in sibs that is $<0.25$, and occurrence of the disease in many different races and in the offspring of mixed race unions (Bundey 1994). Lambert and Lambert (1992) have proposed a corecessive model of inheritance for DNA repair and other surveillance genes requiring mutant alleles acting at at least two loci.
Taylor et al. (1994) reported the existence of AT patients who present an atypical phenotype, for example, milder than expected clinical and cellular features, a partial phenotype, or typical AT, but with additional features. Using 16 patients from 12 families who manifested clear cerebellum ataxia, but whose age of onset was late compared with typical AT patients, they suggested that the variant phenotype maps to the same region of chromosome 11 as the more classic forms of AT, namely the ATM locus. This might suggest the possibility that the variants of $A^{\top} T$ were caused not only by different mutations of ATM, but also by abnormal expression of the NPAT gene, which is tightly linked to the ATM gene.

Interesting properties of the predicted ATM product, especially containing the PI-3 kinase domain, can explain more than one function and its roles specific to each type of differentiated cells, such as Purkinje cells, vascular cells, and T cells. However, identification of the new gene probably encoding a nuclear protein containing cyclin-dependent kinase (cdk) phosphorylation targets and tightly closed to the ATM gene encourages us to suggest that the function of NPAT could be involved in the complex phenotypes of AT.

\section{METHODS \\ cDNA Cloning}

YAC clones mapped to the major AT locus, DA2112B2, 961D6, and 890C12 (Imai et al. 1995), were digested with BssHII or SacII, respectively, and the resulting fragments were ligated with the vectorette linkers as described by Valdes et al. (1994). PCR was carried out in a reaction volume of $25 \mu$ including $1 \times$ EX buffer (Takara, Otsu, Shiga, Japan), $200 \mu \mathrm{M}$ dNTP, $1 \mu \mathrm{M}$ linker primer (Riley et al. 1990), $1.6 \mu \mathrm{M}$ Alu 5'-specific primer (A522: 5' GTGCTGGGATTACAGGCGTGAG-3'), $1.6 \mu \mathrm{M}$ Alu 3'specific primer (A322: 5'-CGACAGAGCGAGACTCCGTCTC-3'), and 2.5 units of EX Taq (Takara). The PCR conditions were denaturation at $95^{\circ} \mathrm{C}$ for 2 min followed by 30 cycles of $30 \mathrm{sec}$ at $98^{\circ} \mathrm{C}$, annealing at $60^{\circ} \mathrm{C}$ for $1 \mathrm{~min}$, and extension for $4 \mathrm{~min}$ at $72^{\circ} \mathrm{C}$. The duration of the extension step was increased by $7 \mathrm{sec}$ each cycle. Amplified 


\section{NEW GENE IN AT LOCUS}

fragments were purified by ultrafiltration with SUPREC-02 (Takara) and used for labeling with $\left[\alpha-{ }^{32} \mathrm{P}\right] \mathrm{dCTP}$.

Human cDNA libraries were constructed with testis or placenta poly $(\mathrm{A})^{+}$RNA (Clontech) and $\lambda$ ZAP cloning vector (Stratagene) according to the procedure recommended by the manufacturer. Plaque hybridization was performed at $65^{\circ} \mathrm{C}$ in $1 \mathrm{M} \mathrm{NaCl}, 10 \%$ dextrin sulfate (Pharmacia), $0.5 \%$ SDS, and $100 \mu \mathrm{g}$ of sonicated human placenta DNA per ml. The ${ }^{32}$ P-labeled amplified DNA fragments were incubated in $500 \mu \mathrm{l}$ of the hybridization buffer containing human placenta DNA at $98^{\circ} \mathrm{C}$ for $10 \mathrm{~min}$ followed at $65^{\circ} \mathrm{C}$ for 15 min before mixing it with the prehybridization solution. Filters were washed finally at $65^{\circ} \mathrm{C}$ in $0.1 \times \mathrm{SSC}$ containing $0.1 \%$ SDS.

Positive clones were isolated and insert DNAs were used for hybridization to blots of the EcoRI digested YACs to confirm whether the cDNA clones were derived from the source YACs.

DNA sequence analysis was carried out with an automatic sequencer (377A, Applied Biosystems) or manually by the dideoxy chain termination method.

\section{Northern and Zoo Blot Hybridization}

Human multiple tissue Northern blots and zoo blot were purchased from Clontech Laboratories. Hybridization to the Northern blots and the following washing were performed according to the procedure recommended by the manufacturer. The zoo blot was hybridized at $65^{\circ} \mathrm{C}$ in $1 \mathrm{M}$ $\mathrm{NaCl}, 10 \%$ dextran sulfate, $0.5 \%$ SDS, and $100 \mu \mathrm{g}$ of yeast tRNA per milliliter. The filter was washed at $55^{\circ} \mathrm{C}$ in $2 \times$ SSC, $0.1 \%$ SDS, and subjected to autoradiography.

\section{Isolation of Cosmid Clones}

High-molecular-weight DNA was extracted from the YAC clones, DA2112B2, 961D6, and 890C12 (Imai et al. 1995). Partially digested DNA fragments by Sau3A were cloned into sCOS-1 vector (Stratagene), and clones containing human DNA were isolated with cot1 DNA (Bethesda Research Laboratories) as the probe. The cosmid DNAs were digested with EcoRI and electrophoresed on $0.8 \%$ agarose gels. DNAs were transferred overnight onto a nylon filter (BA85, Schleicher \& Schuell). Hybridization under stringent conditions with appropriate probes was done as described above.

\section{ACKNOWLEDGMENTS}

We acknowledge with thanks the technical assistance of Kazuhiro Sato. This work was supported in part by the Special Coordination Funds Promoting for Science and Technology Agency, in part by grants from Creative Basic Research (Human Genome Program) from the Ministry of Education, Science and Culture and in part by a Research Grant on Aging and Health from the Ministry of Health and Welfare of Japan. The sequence data described in this paper have been submitted to the DDBJ/EMBL/GenBank data libraries under accession nos. D83243 and D83244.

The publication costs of this article were defrayed in part by payment of page charges. This article must there- fore be hereby marked "advertisement" in accordance with 18 USC section 1734 solely to indicate this fact.

\section{REFERENCES}

Bender, A. and J.R. Pringle. 1992. A Ser/The-rich multi-copy suppressor of a cdc24 bud emergence defect. Yeast 8: $315-323$

Binart, N., B. Chambraud, B. Dumas, D.A. Rowlands, C. Bigogne, J.M. Levin, J. Garnier, E.-E. Baulieu, and M.-G. Catelli. 1989. The cDNA-derived amino acid sequence of chick heat shock protein Mr. 90,000 (HSP 90) reveals a "DNA like" structure: Potential site of interaction with steroid receptors. Biochem. Biophys. Res. Commun. 159: $140-147$.

Bundey, S. 1994. Clinical and genetic features of ataxia-telangiectasia. Int. J. Radiat. Biol. 66: S23-S29.

Cafferkey, R., P.R. Young, M.M. McLaughlin, D.J. Bergsma, Y. Koltin, G.M. Sathe, L. Faucette, W.-K. Eng, R.K. Johnson, and G.P. Livi. 1993. Dominant missense mutations in a novel yeast protein related to mammalian phosphatidylinositol 3-kinase and VPS34 abrogate rapamycin cytotoxicity. Mol. Cell. Biol. 13: 6012-6023.

Cross, S.H., J.A. Charlton, X. Nan, and A.P. Bird. 1994. Purification of CpG islands using a methylated DNA binding column. Nature Genet. 6: 236-244.

Farrelly, F.W. and D.B. Finkelstein. 1984. Complete sequence of the heat shock-inducible HSP90 gene of Saccharomyces cerevisiae. J. Biol. Chem. 259: 5745-5751.

Feinberg, A.P. and B. Vogelstein. 1984. A technique for radiolabeling DNA restriction endonuclease fragments to high specific activity. Anal. Biochem. 137: 266-267.

Feramisco, J.R., D.B. Glass, and E.G. Krebs. 1980. Optimal spatial requirements for the location of basic residues in peptide substrates for the cyclic AMP-dependent protein kinase. J. Biol. Chem. 255: $4240-4245$.

Fernandes, M., H. Xiao, and J.T. Lis. 1994. Fine structure analyses of the Drosophila and Saccharomyces heat shock factor-heat shock element interactions. Nucleic Acids Res. 22: 167-173.

Gatti, R.A., I. Berkel, E. Boder, G. Braedt, P. Charmley, P. Concannon, F. Ersoy, T. Foroud, N.G.J. Jaspers, K. Lange, G.M. Lathrop, M. Leppert, Y. Nakamura, P. O'Connell, M. Paterson, W. Salser, O. Sanal, J. Silver, R.S. Sparkes, E. Susi, D.E. Weeks, S. Wei, R. White, and F. Yoder. 1988. Localization of an ataxia-telangiectasia gene to chromosome 11q22-23. Nature 336: 577-580.

Gatti, R.A., E. Lange, G. Rotman, X. Chen, N. Uhrhammer, T. Liang, S. Chiplunkar, L. Yang, N. Udar, S. Dandekar, S. Sheikhavandi, Z. Wang, H.-M. Yang, J. Polikow, M. Elashoff, M. Teletar, O. Sanal, L. Chessa, C. 


\section{IMAI ET AL.}

McConville, M. Taylor, Y. Shiloh, O. Porras, A.-L. Borresen, R.-D. Wegner, C. Curry, S. Gerken, K. Lange, and P. Concannon. 1994. Genetic haplotyping of ataxia-telangiectasia families localizes the major gene to an $\sim 850 \mathrm{~kb}$ region on chromosome 11q23.1. Int. J. Radiat. Biol. 66: S57-S62.

Greenwell, P.W., S.L. Kronmal, S.E. Porter, J. Gassenhuber, B. Obermaier, and T.D. Petes. 1995. TEL1, a gene involved in controlling telomere length in $\mathrm{S}$. cerevisiae, is homologous to the human ataxia telangiectasia gene. Cell 82: 823-829.

Hari, K.L., A. Santerre, J.J. Sekelsky, K.S. McKim, J.B. Boyd, and R.S. Hawley. 1995. The mei-41 gene of D. melanogaster is a structural and functional homolog of the human ataxia telangiectasia gene. Cell $82: 815-821$.

Harnden, D.G. 1994. The nature of ataxia-telangiectasia: problems and perspectives. Int. J. Radiat. Biol. 66: S13-S19.

Hartley, K.O., D. Gell, G.C.M. Smith, H. Zhang, N. Divecha, M.A. Connelly, A. Admon, S.P. Lees-Miller, C.W. Anderson, and S.P. Jackson. 1995. DNA-dependent protein kinase catalytic subunit: $A$ relative of phosphatidylinositol 3-kinase and the ataxia telangiectasia gene product. Cell 82: 849-856.

Hartwell, L.H. and M.B. Kastan. 1994. Cell cycle control and cancer. Science 266: 1821-1828.

Houldsworth, J. and M.F. Lavin. 1980. Effect of ionizing radiation on DNA synthesis in ataxia telangiectasia cells. Nucleic Acids Res. 8: 3709-3720.

Imai, T., N. Seki, T. Saito, M. Yamauchi, Y. Matsuda, H. Ito, A. Ogiwara, N. Nomura, and T. Hori. 1995. Construction of YAC contigs at human chromosome 11q22.3-q23.1 region covering the ataxia telangiectasia locus. DNA Res. 2: 113-121.

Jaspers, N.G.J., R.A. Gatti, C. Baan, P.C.M.L. Linssen, and D. Bootsma. 1988. Genetic complementation analysis of ataxia telangiectasia and Nijmegen breakage syndrome: A survey of 50 patients. Cytogenet. Cell Genet. 49: 259-263.

Kapp, L.N., R.B. Painter, L.-C. Yu, N.V. Loon, C.W. Richard III, M.R. James, D.R. Cox, and J.P. Murnane. 1992. Cloning of a candidate gene for ataxia-telangiectasia group D. Am. J. Hum. Genet. 51 45-54.

Kastan, M.B., Q. Zhan, W.S. El-Deiry, F. Carrier, T. Jacks, W.V. Walsh, B.S. Plunkett, B. Vogelstein, and A.J. Fornace Jr. 1992. A mammalian cell cycle checkpoint pathway utilizing p53 and GADD45 is defective in ataxia-telangiectasia. Cell 71: 587-597.

Khanna, K.K. and M.F. Lavin. 1993. Ionizing radiation and UV induction of p53 protein by different pathways in ataxia-telangiectasia cells. Oncogene 8: 3307-3312.
Kishimoto, A., K. Nishiyama, H. Nakanishi, Y. Uratsuji, H. Nomura, Y. Takeyama, and Y. Nishizuka. 1985. Studies on the phosphorylation of myelin basic protein by protein kinase $C$ and adenosine 3':5'-monophosphate-dependent protein kinase. J. Biol. Chem. 260: 12492-12499.

Krueger, N.X. and H. Saito. 1992. A human transmembrane protein-tyrosine-phosphatase, PTP $\zeta$, is expressed in brain and has an $\mathrm{N}$-terminal receptor domain homologous to carbonic anhydrases. Proc. Natl. Acad. Sci. 89: 7417-7421.

Kunz, J., R. Henriquez, U. Schneider, M. Deuter-Reinhard, N.R. Movva, and M.N. Hall. 1993. Target of rapamycin in yeast, TOR2, is an essential phosphatidylinositol kinase homolog required for $G_{1}$ progression. Cell 73: 585-596.

Lambert, W.C. and M.W. Lambert. 1992. Co-recessive inheritance: A model for DNA repair and other surveillance genes in higher eukaryotes. Mutation Res. DNA Repair 273: 179-192.

Leonhardt, E.A., L.N. Kapp, B.R. Young, and J.P. Murnane. 1994. Nucleotide sequence analysis of a candidate gene for ataxia-telangiectasia group D (ATDC). Genomics 19: 130-136.

La Thangue, N.B. 1994. DRTF1/E2F: An expanding family of heterodimeric trascription factors implicated in cell-cycle control. Trends Biol. Sci. 19: 108-114.

Liu, V.F. and D.T. Weaver. 1993. The ionizing radiation-induced replication protein A phosphorylation response differs between ataxia telangiectasia and normal human cells. Mol. Cell. Biol. 13: 7222-7231.

Lu, X. and D.P. Lane. 1993. Differential induction of transcriptionally active p53 following UV or ionizing radiation: Defects in chromosome instability syndromes? Cell 75: 765-778.

Matsuda, Y., T. Imai, T. Shiomi, T. Saito, M. Yamauchi, T. Fukao, Y. Akao, N. Seki, H. Ito, and T. Hori. 1996. Comparative genome mapping of the ataxia telangiectasia region in mouse, rat, and Syrian hamster. Genomics 34: (in press).

McConvill, C.M., P.J. Byrd, H.J. Ambrose, T. Stankovic, Y. Ziv, A. Bar-Shira, L. Vanagaite, G. Rotman, Y. Shiloh, G.T. Gillett, J.H. Riley, and A.M.R. Talor. 1993. Paired STSs amplified from radiation hybrids, and from associated YACs, identify highly polymorphic loci flanking the ataxia telangiectasia locus on chromosome 11 q22-23. Hum. Mol. Genet. 2: 969-974.

McConvill, C.M., P.J. Byrd, H.J. Ambrose, and A.M.R. Taylor. 1994. Genetic and physical mapping of the ataxia-telangiectasia locus on chromosome 11 q22-23. Int. J. Radiat. Biol. 66: S45-S56.

Meng, X., V. Jérome, J. Devin, E.-E. Baulieu, and M.-G. Catelli. 1993. Cloning of chicken hsp90ß: The only 


\section{NEW GENE IN AT LOCUS}

vertebrate hsp90 insensitive to heat shock. Biochem. Biophys. Res. Commun. 190: 630-636.

Moore, S.K., C. Kozak, E.A. Robinson, S.J. Ullrich, and E. Appella. 1989. Murine 86- and 84-kDa heat shock proteins, cDNA sequences, chromosome assignments, and evolutionary origins. J. Biol. Chem. 264: 5343-5351.

Morrow, D.M., D.A. Tagle, Y. Shiloh, F.S. Collins, and P. Hieter. 1995. TEL1, an S. cerevisiae homolog of the human gene mutated in ataxia telangiectasia, is functionally related to the yeast checkpoint gene MEC1. Cell 82: 831-840.

Nakai, K. and M. Kanehisa. 1992. A knowledge base for predicting protein localization sites in eukaryotic cells. Genomics 14: 897-911.

Nevins J.R. 1992. E2F: A link between the Rb tumor suppressor protein and viral oncoproteins. Science 258: $424-429$.

Nigg, E.A. 1993a. Cellular substrates of $\mathrm{p} 34^{\mathrm{cdc} 2}$ and its companion cyclin-dependent kinases. Trends Cell Biol. 3: $296-301$.

1993b. Targets of cyclin-dependent protein kinases. Curr. Opin. Cell Biol. 5: 187-193.

Painter, R.B. and B.R. Young. 1980. Radiosensitivity in ataxia-telangiectasia: A new explanation. Proc. Natl. Acad. Sci. 77: 7315-7317.

Paulovich, A.G. and L.H. Hartwell. 1995. A checkpoint regulates the rate of progression through $S$ phase in $S$. cerevisiae in response to DNA damage. Cell 82: 841-847.

Proudfoot, N.J. and G.G. Brownlee. 1976. 5' Non-coding region sequences in eukaryotic messenger RNA. Nature 263: $211-214$.

Riley, J., R. Butler, D. Ogilvie, R. Finniear, D. Jenner, S. Powell, R. Anand, J.C. Smith, and A.F. Markham. 1990. A novel, rapid method for the isolation of terminal sequences from yeast artificial chromosome (YAC) clones. Nucleic Acids Res. 18: 2887-2890.

Sanal, O., E. Lange, M. Telatar, E. Sobel, J. Salazar-Novak, F. Ersoy, A. Morrison, P. Concannon, A. Tolun, and R.A. Gatti. 1992. Ataxia-telangiectasia: Linkage analysis of chromosome 11q22-23 markers in Turkish families. FASEB I. 6: 2848-2852.

Saraste, M., P.R. Sibbald, and A. Wittinghofer. 1990. The P-loop-A common motif in ATP- and GTP-binding proteins. Trends Biol. Sci. 15: 430-434.

Savitsky, K., A. Bar-Shira, S. Gilad, G. Rotman, Y. Ziv, L. Vanagaite, D.A. Tagle, S. Smith, T. Uziel, S. Sfez, M. Ashkenazi, I. Pecker, M. Frydman, R. Harnik, S.R. Patanjali, A. Simmons, G.A. Clines, A. Sartiel, R.A. Gatti, L. Chessa, O. Sanal, M.F. Lavin, N.G.J. Jaspers, A.M.R. Taylor, C.F. Arlett, T. Miki, S.M. Weissman, M. Lovett, F.S. Collins, and Y. Shiloh. 1995a. A single ataxia telangiectasia gene with a product similar to PI-3 kinase. Science 268: 1749-1753.
Savitsky, K., S. Sfez, D.A. Tangle, Y. Ziv, A. Sartiel, F.S. Collins, Y. Shiloh, and G. Rotman. 1995b. The complete sequence of the coding region of the ATM gene reveals similarity to cell cycle regulators in different species. Hum. Mol. Genet. 4: 2025-2032.

Shiloh, Y. 1995. Ataxia-telangiectasia: Closer to unraveling the mystery. Eur. J. Hum. Genet. 3: 116-138.

Sobel, E., E. Lange, N.G.J. Jaspers, L. Chessa, O. Sanal, Y. Shiloh, A.M.R. Taylor, C.M.A. Weemaes, K. Lange, and R.A. Gatti. 1992. Ataxia-telangiectasia: Linkage evidence for genetic heterogeneity. Am. J. Hum. Genet.

50: $1343-1348$.

Swift, M., D. Morrell, R.B. Massey, and C.L. Chase. 1991. Incidence of cancer in 161 families affected by ataxia-telangiectasia. N. Engl. J. Med. 325: 1831-1836.

Taylor, A.M., C.M. McConville, G. Rotman, Y. Shiloh, and P.J. Byrd. 1994. A haplotype common to intermediate radiosensitivity variants of ataxia-telangiectasia in the UK. Int. J. Radiat. Biol. 66: S35-S41.

Thacker, J. 1994. Cellular radiosensitivity in ataxia-telangiectasia. Int. J. Radiat. Biol. 66: S87-S96.

Thiesen, H.-J. and C. Bach. 1990. Target detection assay (TDA): A versatile procedure to determine DNA binding sites as demonstrated on SP1 protein. Nucleic Acids Res. 18: 3203-3209.

Valdes, J.M., D.A. Tagle, and F.S. Collins. 1994. Island rescue PCR: A rapid and efficient method for isolating transcribed sequences from yeast artificial chromosomes and cosmids. Proc. Natl. Acad. Sci. 91: 5377-5381.

Von Lindern, M., M. Fornerod, S.V. Baal, M. Jaegle, T.D. Wit, A. Buijs, and G. Grosveld. 1992. The translocation $(6 ; 9)$, associated with a specific subtype of acute myeloid leukemia, results in the fusion of two genes, dek and can, and the expression of a chimeric, leukemia-specific dek-can mRNA. Mol. Cell. Biol. 12: 1687-1697.

Woodgett, J.R., K.L. Gould, and T. Hunter. 1986. Substrate specificity of protein kinase C. Use of synthetic peptides corresponding to physiological sites as probes for substrate recognition requirements. Eur. J. Biochem. 161: $177-184$.

Yamazaki, M., K. Akaogi, T. Miwa, T. Imai, E. Soeda, and K. Yokoyama. 1989. Nucleotide sequence of a full-length cDNA for $90 \mathrm{kDa}$ heat-shock protein from human peripheral blood lymphocytes. Nucleic Acids Res. 17: 7108 .

Ziv, Y., G. Rotman, M. Frydman, J. Dagan, T. Cohen, T. Foroud, R.A. Gatti, and Y. Shiloh. 1991. The ATC (ataxia-telangiectasia complementation group C) locus localizes to 11 q22-q23. Genomics 9: 373-375.

Received February 7, 1996; accepted in revised form March 26, 1996. 


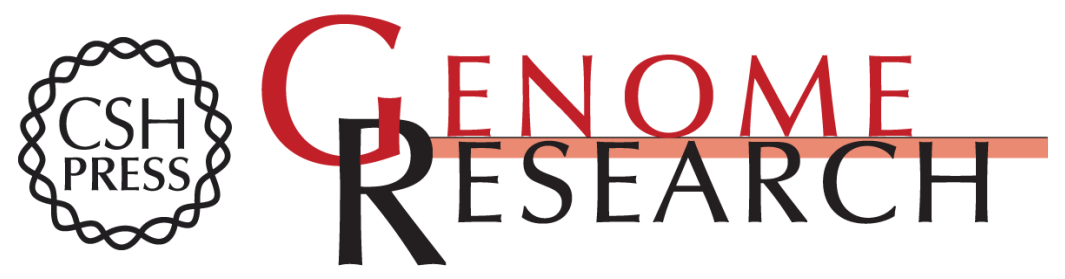

\section{Identification and characterization of a new gene physically linked to the ATM gene.}

T Imai, M Yamauchi, N Seki, et al.

Genome Res. 1996 6: 439-447

Access the most recent version at doi:10.1101/gr.6.5.439

References This article cites 58 articles, 13 of which can be accessed free at:

http://genome.cshlp.org/content/6/5/439.full.html\#ref-list-1

\section{License}

Email Alerting Receive free email alerts when new articles cite this article - sign up in the box at the Service top right corner of the article or click here.

\section{Affordable, Accurate Sequencing.}

To subscribe to Genome Research go to:

https://genome.cshlp.org/subscriptions 